\title{
Are the art treasures and the overseas students safe?
}

LAST week it was Mr Reg Prentice's turn, as Secretary of State for Education and Science, to appear at the House of Commons Select Committee's hearing on the financing of scientific research in British Universities. To his sympathetic questioners he declared that the universities were marginally more able, twelve months ago, to bear cuts in their funding than were most other parts of the educational system. There had been a generosity in the staffstudent ratio which could bear a little squeezing, but now that had been done, and he did not think one could any longer generalise on the ability of universities to stand further onslaughts. But perhaps some well-endowed establishments might sell off a few of their oil-paintings to tide them over the crisis. The British Antique Dealers' Association pronounced the idea "morally reprehensible".

If we are down to dusting off the art treasures, then we are also at the level at which some other appurtenances of university life are vulnerable. The committee has already had a nose around unproductive research without much in the way of enthusiastic response from its witnesses. Where it does seem to be generating some momentum of its own is on the issue of postgraduate students from overseas. Thus $\mathrm{Mr}$ Norman Tebbit asked Mr Prentice whether overseas students were not occupying too much of the "well found" floor space supported by the University Grants Committee (UGC) and hence the taxpayer. Mr Prentice gave the standard deadbat response that there were long-term diplomatic and commercial benefits to having overseas students here.

It was clear that there is a view on the committee not only that overseas students could be charged rather more for their time here but also that there are some cases where the benefits of having overseas students are mainly benefits to the sending countries. This view is helped along by two observations: first that there are departments, particularly in the applied sciences, where overseas postgraduates are in the majority and, second, that although nobody is questioning the concept of aid to developing countries through the provision of university education, a growing number of postgraduate places is being taken up by students from the developed world.

The concern is a reasonable one within many people's concept of what a university should be, and deserves serious attention. In the five years from 1968 to 1973 the number of those obtaining higher degrees (in all subjects) has grown steadily from around 10,000 to around 14,000 a year. (Roughly $40 \%$ of these degrees are doctorates.) While the number of Commonwealth higher-degree recipients has remained static at about 1,500 , the numbers from other countries has doubled from 1,000 to 2,000 . In $1973,27 \%$ of all recipients of higher degrees were from overseas-in pure science $22 \%$, in applied science $36 \%$. About $60 \%$ of overseas students returned home after obtaining their degree. In the same year 376 first-degree
British graduates went overseas for further education; this figure has declined from 538 in 1970. Most recent figures show that overseas students now account for $33 \%$ of postgraduates and applied sciences probably over $40 \%$.

Britain gives more than she takes in higher education, and fairly clearly she has been giving more to students from developed countries in recent years. Is there a case for any control of numbers? The reasons normally advanced against the suggestion are not the most compelling.

Although it is true that the training of students here generates a lot of goodwill in academic, industrial and governmental life around the world, it would be difficult to demonstrate that this creates much in the way of hard returns beyond providing professors with a choice of venue for their sabbaticals. If postgraduate training increases sophistication in students, it must be assumed that they are unlikely to be swayed in the purchase of, say, some piece of equipment by the fact that they went to university in the country in which the makers are situated. And if a piece of equipment being considered is one with which they had experience when in Britain, it is entirely possible that it was imported into Britain or did not prove satisfactory (or both).

The diplomatic profit argument is no easier to sustain. Armies lead by Sandhurst-trained officers have been known to act in other than Britain's interests. Is there any evidence that London-trained ministers of trade, technology, communications, oil and so on look any more kindly on the country in which they obtained their postgraduate education? Any Harvard-trained minister in the British government who started favouring US business would soon be out on his ear.

There are two much better arguments for encouraging the flow of overseas students-one idealistic, one chauvinistic. On the idealistic plane, Britain supports universities because they are places of learning, and learning, even in the applied sciences, knows few frontiers. True, the man with the key patent will profit himself and his own country first, but the benefits very quickly flow to the users as well as the inventor. And the inventor will have had to dip into a truly international pool of knowledge. Thus talk of great new British inventions, so beloved of newspapers, is often meaningless. The more the international character of learning is stimulated by the interchange of people, the more broadly and effectively does the academic life operate. (But fewer Britons are going abroad for postgraduate education.)

On the chauvinistic level, every postgraduate who comes to Britain is potentially capable of making a significant intellectual contribution even within a threeyear period-and many do. It is often forgotten that some do their best work when still a student, and this work is then immediately available in the British community. Besides which, many stay for the rest of their lives. 